\title{
Nagy Stella - Nagy Zoltán
}

\section{Okos közlekedési fejlesztés a miskolci autóbusz menetrend példáján keresztül}

Tanulmányunkban az okos város dimenziók egyik elemének, az okos közlekedésnek egyik jellemzöjét, egy forgalmas autóbusz járat menetrendjét vizsgáljuk. Miskolc város eddig is több erőfeszitést tett a közlekedés irányitásnak, szervezésének, követésének okosabbá tétele felé. Az 1es viszonylaton végzett menetidő vizsgálatokra alapozva fogalmaztunk meg egy másik menetrendi megoldást, hiszen az okos megoldások alkalmazásánál a késések mellett a siető járatok is hátrányosak lehetnek az utazóközönségnek, pl. a tervezhetöség nehezebbé válása miatt. Emellett egy smart és zöld közösségi közlekedési rendszer lehetséges elemeit mutatjuk be egy tanulmány alapján.

Kulcsszavak: okos város, okos közlekedés, menetrendi idők optimalizálása JEL-kód: R10, R40

https://doi.org/10.32976/stratfuz.2021.9

\section{Bevezetés}

A smart city megnevezéssel nagyon gyakran találkozhatunk a szakirodalomban és a mindennapi életben is, azonban még továbbra nincs egységes megállapodás arról, hogy a fogalom milyen elemeket hordoz magában (Nagy et al. 2015). Az okos város koncepció esetében az egyik legmeghatározóbb szakirodalmi forrásnak Giffinger 2007-es tanulmánya tekinthetö, mely alapján a smart city egy olyan város, amely kimagaslóan teljesít hat jellemző esetén, melyek a következők: okos környezet, okos életkörülmény, okos emberek, okos kormányzás, okos gazdaság és okos mobilitás (Giffinger et al. 2007). Hall (2000) szerint az okos város olyan város, mely egyidejüleg minden kritikus infrastruktúrát megfigyel és integrál, és jobban optimalizálja erőforrásait, megtervezi tevékenységeit, ellenőrzi a biztonsági szempontokat, és eközben maximalizálja a lakosság számára nyújtott szolgáltatásokat. Komninos (2011) szerint az okos városokat az jellemzi, hogy a tudás és innováció aránya nagyon magas, és ezt egyrészt a város kreatív lakossága, másrészt a digitális infrastruktúra és a tudásmenedzsment biztosítja. A szakirodalomban látható sokszínűség alapján elmondható, hogy az okos város tulajdonképpen egy komplex fogalom. Olyan város, amely innovatív stratégiát és megoldásokat alkalmaz annak érdekében, hogy javítsa a lakosság életminőségét, miközben hatékonyan használja a lakosság kreativitását és tudásbázisát (Szendi 2019).

Ezen koncepció egyik dimenziója az okos mobilitás alrendszer, mely egy valós idejű adatok alapján müködő közlekedési rendszert jelent, ami az emberi tudást, intelligenciát és döntési folyamatokat is ötvözi (Földes 2019). Az okos közlekedési rendszer esetében összekapcsolódik az információs technológia az infrastruktúrával, szervezetekkel, személyekkel és az általuk használt eszközökkel a társadalmi, gazdasági, kulturális és környezeti kihívások komplex problémakörének megoldása érdekében (Szlávik 2013). Erhart Szilárd (2007) kiemeli, hogy napjaink városi közlekedésében ,a megnövekvő utazási idő miatt csökken a munkára és szabadidős tevékenységekre felhasználható időkeret. Az alacsonyabb sebesség miatt a gépjármüvek energiafelhasználása emelkedik, ennek hatására növekszik az üzemanyagköltség, valamint a környezetszennyezés és az egészségkárosodás mértéke is" (Erhart 2007 451). Mindezek alapján megállapítható, hogy az okos mobilitás dimenzió jelentősége egyre inkább növekszik napjainkban.

„Kiszámíthatóan, kulturáltan, biztonságosan, valamint energiatakarékos és környezetbarát módon szállítjuk utasainkat" áll az MVK Zrt. missziójában egy 2013-ban megjelent tanulmányban (MVK Zrt. 2013). Az első kritérium a kiszámíthatóság, mely azt jelenti, hogy a menetrend szerint 
közlekedő járművek ne térjenek el a tervezett útvonaltól és menetidőtől. Az utóbbi időben a számos okos mobilitáshoz kapcsolódó fejlesztésnek köszönhetően egy korszerü, GPS adatokon alapuló utastájékoztató rendszert építettek ki. Ez egy nagy elörelépést jelentett, azonban a járművek adatszolgáltató berendezései által generált információ elemzése nélkül nem alakítható ki megbízható menetrend, mely a kiszámíthatóságot szolgálná.

Az informatikai rendszerek több, a forgalmi eseményeket leképező információt is rögzítenek, amelyeket általában irányítási, elszámolási és minőségellenőrzési funkciókra használnak fel. A leképezett adatbázis azonban más operatív célokra is alkalmas, úgy, mint a menetrendek optimalizálására, mely kulcstényező a közösségi közlekedés alakításában. A menetrendi idők meghatározása és a menetrendek kialakítása bonyolult számításokon alapul, azonban elengedhetetlen a historikus adatok elemzése ahhoz, hogy a menetrendi tervadatok a gyakorlatban is megvalósíthatók legyenek, így korrekcióra lehet szükség. A kutatás során az MVK Zrt. által rendelkezésünkre bocsátott adatokon alapuló eltéréselemzést végeztünk arra vonatkozóan, hogy valóban kiszámítható-e jelenleg a miskolci menetrend, illetve számításokat készítettünk annak érdekében, hogy az eltérések esetében pontosabb menetrendi idők legyenek feltüntetve (SándorCsiszár 2013). Természetesen látjuk, hogy napjaikban a nagyvárosi közösségi közlekedési rendszerek komoly nehézségekkel, finanszírozási problémákkal, forráshiánnyal küzdenek hazánkban. Sok esetben nem a menetrendi optimalizáció van napirenden, hanem a járatcsökkentés, esetlegesen járatok átalakítása, megszüntetése. Tanulmányunkban egy menetrendi problémára elméleti megközelítést adunk, és egyes okos megoldások felsorolásával egy smart és zöld közösségi közlekedési rendszer lehetséges elemeit mutatjuk be egy tanulmány alapján.

\section{Menetrendi idők elemzése és optimalizálása}

Miskolc város közösségi közlekedése meglehetősen komplex vonalhálózattal rendelkezik. A településen jelenleg a közösségi közlekedési járatok 45 viszonylaton 148 útvonalvezetésen közlekednek, így a naponta elindított járatok száma megközelíti a 4000-ret. Ezen járatokra vonatkozó historikus adatok a ForTe Forgalomirányítási és Utastájékoztatási Rendszerből viszonylatonként kérdezhetök le.

\section{Elözetes lehatárolások}

A ForTe rendszer rengeteg feldolgozható adatot tartalmaz, és a 2020-as menetrendnél javasolt számolni a valós értékekhez közel álló, átlagolt adatokkal, szem előtt tartva a forgalmi viszonyokat is. A cégnél alkalmazott korrekciós folyamatoknak megfelelően a menetrend kiszámíthatóságának meghatározásánál egy olyan átlagos forgalmú hónap (teljes iskolai forgalmat tartalmazó, ünnep és munkanap áthelyezések nélküli) adatait vettük alapul, amely esetében mind az időjárási, mind pedig a forgalmi viszonyok tipikusnak tekinthetők, így ebben az esetben a 2020. februári rekordokat vizsgáltuk meg.

$\mathrm{Az}$ adott hónapban a vezetöség által közölt információk alapján semmilyen rendkívüli esemény nem történt, így a februári hónapból képzett minta megfelelően reprezentálja az átlagos forgalmi viszonyokat. Eltérő menetrendi időket szükséges a munkanapok, valamint a munkaszüneti- és szabadnapok esetében is alkalmazni, így ezen napokat külön vizsgálatok során lehet csak elemezni. Jelen tanulmány a februári munkanapok adatainak analizálásán alapul, mivel az ezen napokon jelentkezik a legmagasabb a forgalom, valamint a legmagasabb járatszám is.

Az időbeli lehatároláson felül egy viszonylat, az 1-es számú autóbuszviszonylat, azon belül is az A672-es számú útvonalvezetés került kiválasztásra, mely példaként szolgálhat az elemzés módszertanának bemutatására. A fent említett viszonylat kiválasztását indokolja, hogy Miskolc közösségi közlekedésében ez az egyik leghosszabb útvonal, így ebben az esetben kifejezetten nagy hatása lehet az egyes megállók közötti menetidő helytelen meghatározásának, mivel a magasabb számú megállók esetén tapasztalt eltérések kumuláltan magasabb eltérést eredményezhetnek, ezáltal pontatlanabb lehetet a menetrendi tervidő. Az A672-es számú útvonalvezetés 25 megállót 
érintve a Majális-park-Tiszai pályaudvar viszonylaton közlekedik. A $13 \mathrm{~km}$ hosszú szakasz megtétele közben a járat olyan forgalmas pontokon is áthalad, mint a Búza tér, a Vologda városrész, vagy az Újgyőri főtér.

Az ilyen formában történő lehatárolások segítségével tárhatók fel azon autóbuszjáratok, amelyek menetrendi adatainál korrekcióra lehet szükség. Abban az esetben lehet a módosítást elvégezni, ha az eltérés egyértelmű okaként a menetidő helytelen meghatározása jelölhető meg.

\section{A ForTe rendszerböl lekérdezett adatok}

A ForTe rendszerből a kinyert adatok között a következő típusú információk szerepeltek: feldolgozhatóság, dátum, viszonylat, útvonal vezetés, forgalmi szám, szolgálati szám, tény jármü, járművezető, indulási hely, terv indulási idő, tény indulási idő, terv érkezési idő, tény érkezési idő, terv menetidő, tény menetidő. A lekérdezést követően a táblázat 9900 adatrekordot tartalmazott, mely adatok közül a vizsgálat szempontjából relevánsnak a dátum, terv menetidő, és tény menetidő kategóriákba tartozó információk számítottak, ezek segítségével végeztük el a terv-tény elemzést. Az 1. ábrán az indulási időpontokhoz tartozó maximális, valamint minimális tényleges menetidőket kerültek szemléltetésre 2020 februárjának historikus adatai alapján.

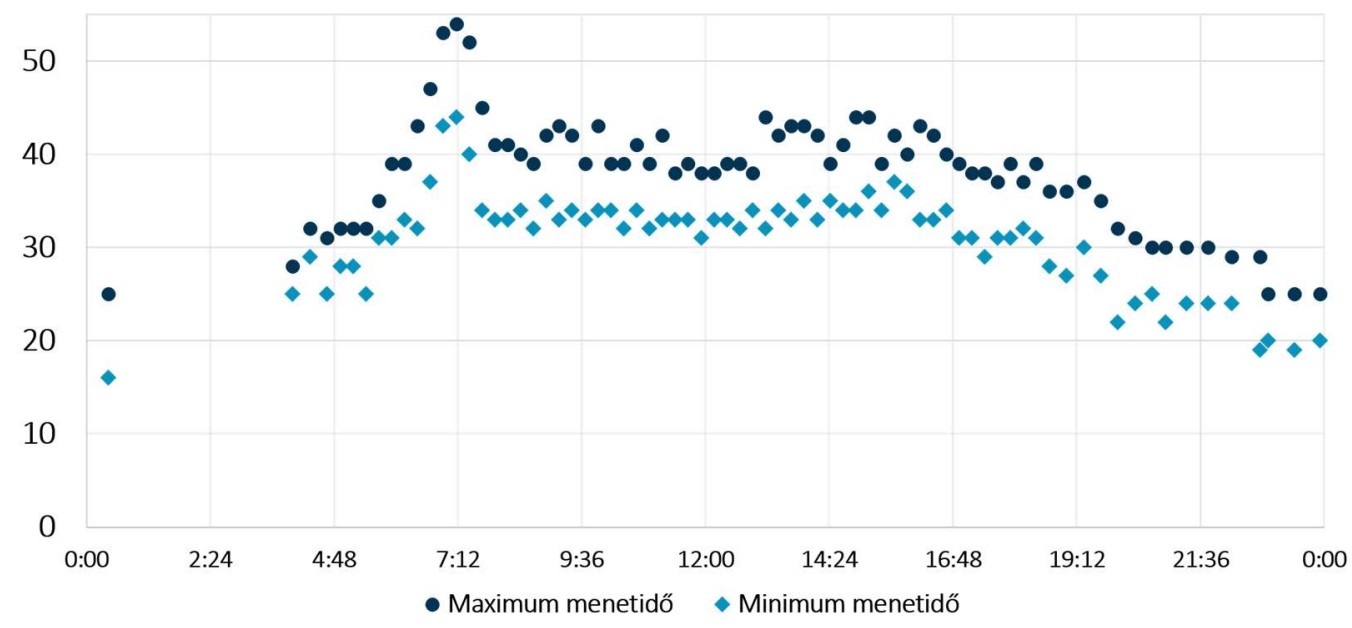

1. ábra: Az indulási időpontokhoz tartozó maximális, illetve minimális tényleges menetidők 2020 februárjában (perc)

Figure 1: Maximum or minimum actual journey times for departure times in February 2020 (minutes)

Forrás: MVK Zrt. adatai alapján saját számítás

A legmagasabb menetidők a reggeli csúcsidőszakban, a 7:00 és 8:00 között indított járatok esetében jelentkeznek, ezt követöen 14:00-ig a forgalom azonban közel azonos menetidőket tesz lehetővé. A délutáni csúcsidőszakban 16:00-tól ismét jelentősen megnő a minimális és a maximális menetidő, majd a késő esti órákban egyre alacsonyabb értékeket vesz fel. Az egyes menetrendszerinti járatok tervezett menetidejétől való eltérések terjedelme 3 perc és 12 perc között mozog, a maximális érték 54 perc, míg a minimum 16 perc volt a vizsgált időszakban. A tervezett legrövidebb menetidő 23 perc, míg a legmagasabb 41 perc, így érzékelhető, hogy milyen magas eltéréseket mutathatnak a valós adatok a tervezetthez képest, így indokolt lehet a menetidő korrekció elvégzése. 


\section{Menetrendi adatok eltéréselemzése}

Az eltéréselemzést egy, a gyakorlatban jelenleg is alkalmazott 3 lépésből álló módszer segítségével végeztük el, melynek lépései a következők:

1. lépés: Az egyes terv- és tényadatok különbségének meghatározása járatonként.

2. lépés: Az egyes indulási időpontokhoz tartozó eltérések átlagos értékének kiszámítása, a kritérium tartományon kívül eső eltérési idők meghatározása.

3. lépés: A késő és siető járatok menetidejének korrekciója átlagszámítás segítségével.

\section{1. lépés: Az egyes terv- és tényadatok különbségének meghatározása járatonként.}

Minden egyes nap minden egyes indulási idő pontja esetében a következő képlet használatával határoztuk meg a tervezett menetidőtől való tényleges elérést:

Tény menetidő - Terv menetidő = Eltérés (percekben)

A képlet alkalmazásával a negatív eredmény a menetrendhez képest sietést, a pozitív eredmény pedig késést jelentett percekben. Összesen 1100 ilyen adatrekord került meghatározásra, melyek átlaga $-0,94$ perc, az átlagtól pedig 2,83 perccel térnek el átlagosan az egyes adatok, amelyek 22 perces terjedelemben szóródnak. Az eltérések leggyakoribb értéke - 2 perc, tehát a vizsgált menetidők esetében a leggyakoribb eltérés a 2 perces sietés volt, míg az átlagtól való négyzetes eltérés 8,02 perc. A csúcsosság pozitív, 2,61-es, míg a ferdeség is pozitív, 0,84 -es értéket vesz fel. Az eltérési adatok sokaságáról elmondható, hogy csúcsos, valamint jobbra ferde eloszlású (Sajtos-Mitev, 2007).



2. ábra: A tervezett menetidőtől való eltérések eloszlásának hisztogramja

Figure 2: Histogram of the distribution of deviations from the proposed journey time Forrás: MVK Zrt. adatai alapján saját számítás

A tervezett menetidőtől való eltérési adatok eloszlását hisztogramon szemléltetve (2. ábra) is jól látható, hogy csúcsos, jobbra ferde eloszlás jellemző rá, így megállapítható, hogy az értékek nagy része a medián körül szóródik, melynek értéke -1, valamint inkább a negatív értékek felé tolódik, tehát inkább jellemző a sietés, mint a késés. A ferdeségből adódóan az esetleges korrekciónál az új menetrendi értékek meghatározása a mediánból kiindulva nem történhet meg, helyette az átlagszámítást célszerü alkalmazni. Az intervallumok 1 percenként kerültek beosztásra, a legalacsonyabb érték -9 perces eltérés, míg a legmagasabb 13 perces eltérés volt, így a terjedelem 22 perces értéket vett fel. Az eltérési adatok interkvartilis terjedelme 4 perc, mely azt jelenti, hogy az adatok fele esik bele ebbe a 4 perces intervallumba (Sajtos-Mitev 2007). 


\section{2. lépés Az egyes indulási időpontokhoz tartozó eltérések átlagos értékének kiszámítása.}

A terv-tény elemzés második lépéseként meghatároztuk a menetrendtől való eltérések átlagos értékét indulási időpontonként. Az MVK Zrt. szabályzata alapján abban az esetben beszélhetünk menetrendtől eltérő járatról, ha az adott időpontban induló járat havi átlagos menetrendtől való eltérése percekben mérve a $[-2 ; 2]$ intervallumon kívül esik. Ha az eltérés negatív irányú, akkor sietést, ha pedig pozitív irányú, akkor késést jelent.

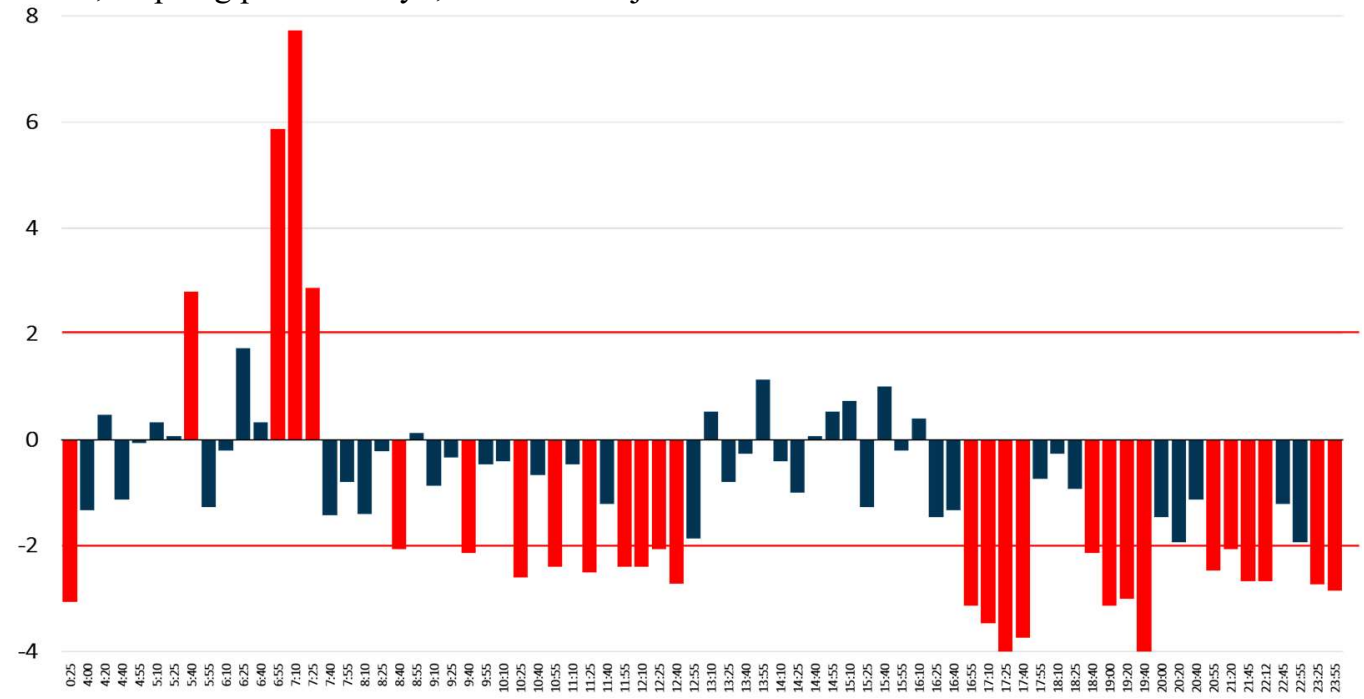

3. ábra: A hétköznapi indulási időpontokhoz tartozó átlagos eltérések 2020. februárjában (perc)

Figure 3: Average deviations from the workaday departure times in February 2020 (minutes)

Forrás: MVK Zrt. adatai alapján saját számítás

A 3. ábra diagramjáról az egyes indulási időkhöz tartozó átlagos menetrendtől való menetidőeltérések mértéke olvasható le, ahol a kritérium tartományon kívül eső értékeket piros színnel, míg a szabályzatnak megfelelő eltérési értékeket sötétkék színnel jelöltük. Mindezek alapján elmondható, hogy az esetek szignifikáns részénél a menetidőkbe történő beavatkozásra van szükség, hiszen az átlagos adatok nem minden esetben teljesítik a szabályzatban foglalt feltételt. Az is megállapítható, hogy míg a reggeli csúcsidőszak esetén jellemzően pozitív, addig a délelötti, valamint késő esti órákban negatív a menetidőeltérés, így az adott időszakban a reggeli járatok késéssel közlekedtek, míg a délelőtt, illetve a késő este indított járatok hamarabb értek célba a tervezett időhöz képest.

A járatok 62,2\%-a esetében a menetrendtől való átlagos eltérés kritérium tartományon belül esik, így ezek megfelelnek a követelményeknek. A járatok 37,4 \%-ánál azonban az átlagos eltérés 2 percnél magasabb, így ezen esetében a menetrendi idő módosítására lehet szükség. A hétköznapi járatok 32,4\%-a siet, 5,4\%-a pedig késik a menetrendben meghatározott tervidökhöz képest.

\section{3. lépés A késő és siető járatok menetidejének korrekciója átlagszámítás segítségével.}

A 3. lépésben a fentieknek megfelelően azonosított késő, illetve siető járatok menetrendi közlekedési idejének korrekcióját végeztük el, olyan módon, hogy indulási időpontonként a 2020 februári historikus menetidők átlagát alapul véve minden egyes esetben a legközelebb eső egész percre kerekítettük felfelé az értékeket, mivel ilyen módon megakadályozható, hogy jelentősebb mértékben késsenek a járatok.

A vizsgált járatok közül 4 esetben volt szükség az eredeti értéknél hosszabb menetidö meghatározására, míg 25 esetben az új javasolt menetidő az eredetinél rövidebb. A 
legszignifikánsabb változtatást a reggeli csúcsidő kezdetén lehet eszközölni, mivel ezen autóbuszjáratok esetében akár 6-8 perccel is növelni kell a menetidőt. Az esetek nagy részénél csak kisebb módosítást, a menetidő 2 perccel történő csökkentését szükséges elvégezni, az új értékeket a ForTe rendszerben rögzíteni. Az új megadott menetrendi idők minimuma 23 perc, amely megegyezik az eredeti menetrendi idők minimumával, míg a javasolt módosítások után a leghosszabb menetrendi idő 41 perc helyett 49 perc is lehet. Ebben az esetben felvetődik a kérdés, hogy érdemes-e a menetidőt megváltoztatni és hozzáigazítani a tapasztalt eltérésekhez, vagy inkább a buszközlekedést célszerübb alakítani, gyorsítani pl. okoslámpák, vagy további buszsávok kialakításával csökkenteni a menetidőt?

\section{A menetrend korrekciójának hatásai}

A mentrendi korrekció elvégzése után ismételten meghatároztuk a tényadatok menetidőtől való eltérését, valamint az előzőekben kiszámított mutatókat is. A korrekció hatására az átlag közelít a 0-hoz, 0,07 perces értéket vesz fel, míg az átlagtól való átlagos eltérés mértéke 2,8 percröl 2,4 percre csökken. A leggyakoribb érték az -1 perc, azaz az 1 perces sietés, amely teljes mértékben megfelel az elöírásoknak, míg a középső érték (medián) is -1 perc lesz. Az adatok terjedelme is csökkent, 22 percről 17 perces értékre módosul.

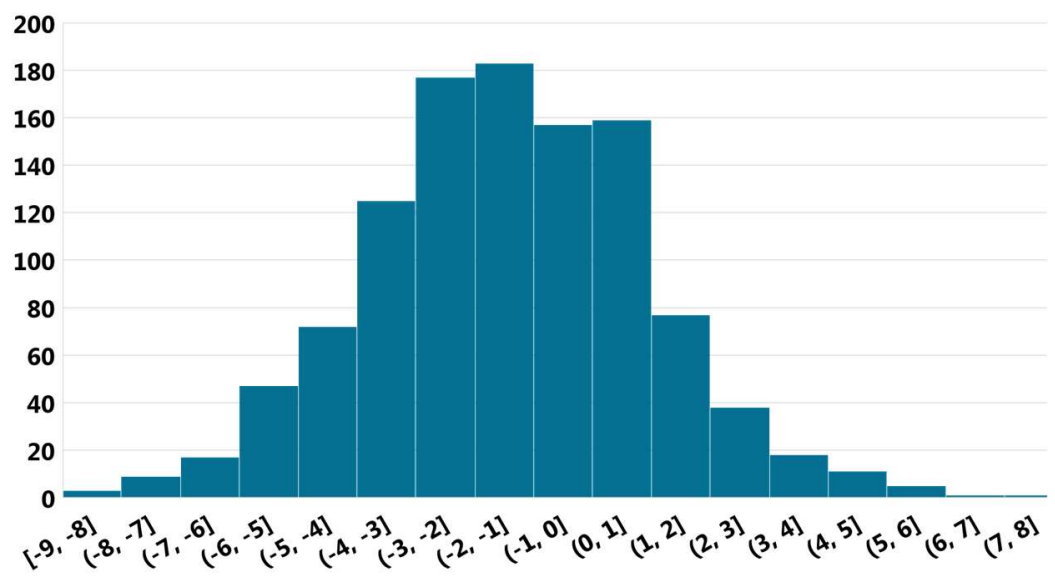

\section{4. ábra: A javasolt korrekciók elvégzése utáni új mentrend tervezett menetidőitől való eltérések eloszlásának hisztogramja}

Figure 4: Histogram of the distribution of deviations from the planned journey times of the new timetable after the proposed corrections have been made

Forrás: MVK Zrt. adatai alapján saját számítás

A 4. ábra hisztogramján jól látható, hogy a módosításnak köszönhetően a jobb oldali ferdeség az eloszlás esetében megszünt, azonban csúcsos maradt, amely arra enged következtetni, hogy ha a jövőben a tényleges adatok valóban hasonló tendenciát fognak követni, mint 2020 februárjában, akkor nem várható olyan változás, amely azt eredményezné, hogy menetidők áltagos eltérésének mértéke ne a $[-2 ; 2]$ intervallumba essen, ezáltal biztosítva lehet a szabályzatban megfogalmazott követelmény teljesítése.

Az adatok a korrekciónak köszönhetően jelentősen kisebb terjedelemben szóródnak. Az eltérések fele egy 3 perc terjedelmü intervallumba, az alsó kvartilis (-2 perc) és a felső kvartilis (1 perc) értékei közé esik. Mivel az adatok 50\%-a ebben az intervallumban helyezkedik el, ezen értékek egyértelmủen megfelelnek az elöírásnak, a jövőben pedig hasonló tendenciát követve várhatóan is teljesítik azt. Az alsó kvartilis magasabb értéket kapott, így elmondható, hogy a késések mértéke várhatóan jelentősen alacsonyabb lesz. 


\section{További fejlesztési irányok felvázolása}

Napjainkban a közösségi közlekedést a miskolci lakosok körülbelül 40\%-a választja a napi közlekedése során, az autóbusz- vagy villamosjáratok körülbelül több, mint 63700 fő mobilitási igényeit szolgálják ki. A legkisebb arányt a gyalogosok és kerékpárosok képviselik, míg gyalogosan $10 \%$, addig kerékpárral mindössze a városlakók 5\%-a közlekedik (Közlekedés Fővárosi Tervező Iroda Kft. 2016).

Az MVK Zrt. fő célkitüzése az, hogy a közösségi közlekedést választók aránya a következő években növekedjen, miközben a misszióban megfogalmazott 5 kritériumot (kiszámíthatóság, kulturáltság, biztonság, energiatakarékosság, környezetvédelem) is teljesítik. A Közlekedés Fővárosi Tervező Iroda Kft. által készített 2017-es Miskolc megyei jogú város közlekedésfejlesztési koncepció és programban is megjelenik ezen cél, miszerint 2030-ra a tervek szerint a kötöttpályás villamosközlekedés, a vonzáskörzetből helyközi vasúttal együttesen, valamint a kombinált-közösségi autóhasználat a városi közösségi közlekedés arányát $50 \%$-ra növelné, míg az egyéni autózás 20\%-ra csökkenhetne, melynek köszönhetően a városi környezeti terhelés enyhül, az eljutási idő csökkenne, a parkolás racionalizálása is megtörténhetne.

\section{Egy smart és zöld közösségi közlekedési rendszer elemei Miskolcon}

Véleményünk szerint a közösségi közlekedés esetében egy okos rendszer kialakítása leghatékonyabban az ökoszisztéma szemléletmód alkalmazásával érhető el a külön álló fejlesztések megvalósítása helyett. A 5. ábrán személtettük a Közlekedés Fővárosi Tervező Iroda Kft. 2017-es tanulmányában említett fejlesztések integrálásával kidolgozott jövőképet, amely alapján kialakítható lenne a miskolci okos mobilitási rendszer az ökoszisztéma szemléletmód alkalmazásával.

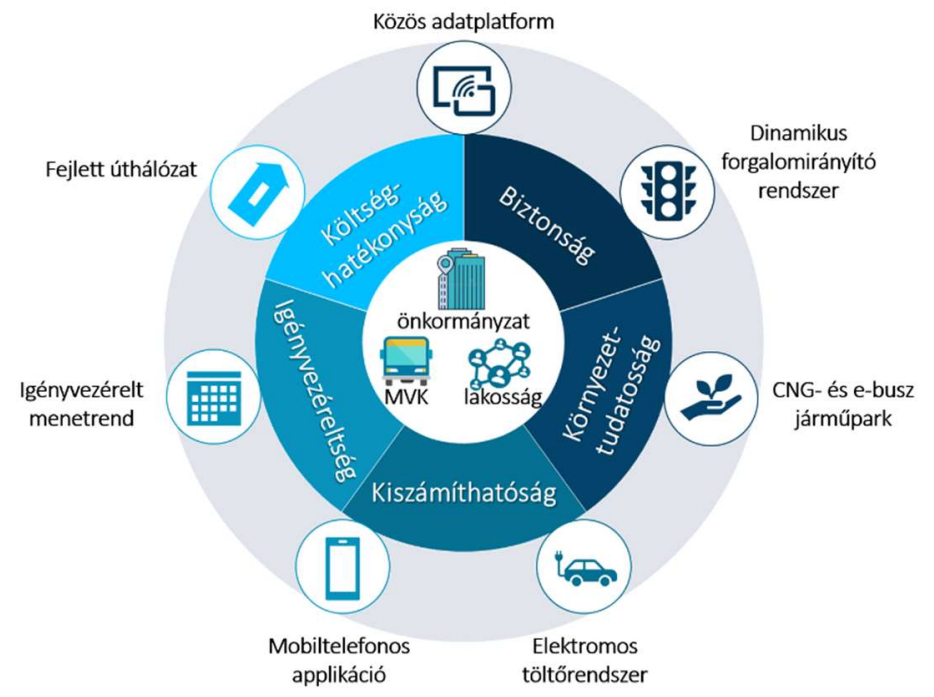

5. ábra: Miskolc város okos közösségi közlekedési ökoszisztémájának jövőképe

Figure 5: The vision of the intelligent public transport ecosystem of the city of Miskolc Forrás: Közlekedés Fővárosi Tervező Iroda Kft. 2017-es tanulmánya alapján saját szerkesztés

Az ökoszisztémában 3 szintet határoztunk meg: a szereplök, a követelmények és az eszközök szintjét. A szereplök között a miskolci közösségi közlekedés által közvetlenül érintett három szereplöt tüntettük fel. Az önkormányzat, mint döntéshozó és finanszírozó, az MVK Zrt. mint döntéshozó, szolgáltató és megvalósító, valamint a lakosság, mint felhasználó és finanszírozó jelenik meg a modellben.

A következő szint a kritériumok szintje, amely azon elvárásokat foglalja magában, amelyeket az

okos mobilitási rendszerrel szemben támasztanak az egyes szereplők. Egyértelmü 
követelményként jelenik meg a biztonság minden szereplő szempontjából, hiszen a cél végső soron az emberek mobilitásának biztonságos kiszolgálása. A környezettudatosság egyre fontosabb szerepet tölt be a lakosság szemléletmódjában is, valamint a jogszabályi elóírások miatt a szolgáltató és az önkormányzat számára is kiemelt kritériumot jelent. Mind az MVK Zrt., mind pedig a lakosság alapvető elvárása a kiszámíthatóság, hiszen csakis akkor működik jól a rendszer, ha a szolgáltató tervei valóban megvalósulnak, a felhasználók kényelmét pedig akkor szolgálja megfelelően, ha a szolgáltató által elöre közölt információk a gyakorlatban is megállják helyüket. Az igényvezéreltség alapvető elvárás a mai okos mobilitási rendszerek tekintetében, mivel ez a felhasználók érdekét szolgálja, valamint hatással van a költséghatékonyságra is, amely a szolgáltató és az önkormányzat számára is jelentős tényező. A PwC Magyarország Kft. 2016-os tanulmánya alapján a magas színvonalú közösségi közlekedés csak megfelelő szintű bevételekkel érhető el. Ahhoz pedig, hogy az MVK Zrt. megfelelő bevételre tegyen szert, olyan szolgáltatást kell nyújtania, amit a lehető legtöbben vesznek igénybe.

A harmadik szint, azon eszközöket, fejlesztéseket foglalja magában, amelyek segítségével egy olyan okos közösségi közlekedési ökoszisztéma jön létre, amely teljesíti a szereplők által támasztott követelményeket.

\section{Közös adatplatform}

A minden nap keletkező nagy mennyiségü adat miatt Miskolc esetében is elengedhetetlen egy olyan közös adatplatform létrehozása, ahol mind a közúti forgalmi, mind pedig a közösségi közlekedési adatok egy helyen elemzésre kerülnek algoritmusok segítségével. Ezen adatplatform lehetővé tenné az információk valós idejü összegyüjtését, monitorozását, valamint segíthetné a döntéshozatalt, az optimalizálást is. A döntéseket így több tényező figyelembevételével lehetne meghozni, amely által az egész közlekedési rendszert optimalizálni lehetne. A rendszer lehetőséget adhat a közúti forgalmi és utasforgalmi mintázatokat hatékonyabb feltárására és az azokra való gyors és megfelelö reagálásra (Sallai 2018).

Dinamikus forgalomirányitó rendszer (okos jelzölámpák, burkolatok, kamerák)

A dinamikus forgalomirányító rendszer magában foglalná a forgalomirányítási rendszer informatikai hátterét, illetve azon eszközöket (okos jelzőlámpák, okos burkolatok, forgalomszámláló kamerák), amelyek a közúti forgalom optimalizálását és biztonságát szolgálják. Egy ilyen rendszer lehetővé tenné a gerincútvonalak forgalomfüggő szabályozását, a dinamikus sáv és sebességmenedzsment megvalósítását, a közösségi közlekedés priorizálását, vagy a dinamikus parkolásirányítást (Közlekedés Fővárosi Tervező Iroda Kft. 2017).

\section{$C N G$ - és e-busz jármüpark}

A jelenlegi $75 \mathrm{CNG}$ autóbusz mellé további kb. $70 \mathrm{db}$ ilyen üzemeltetésű jármű beszerzését tervezi az MVK Zrt., amelynek köszönhetően egy teljes mértékben modern jármüpark jönne létre. A gázhajtás költségmegtakarítást eredményez, valamint az emissziós értéke is jelentősen kisebb, mint a hagyományos benzinmotorral müködő autóbuszoknak. A későbbiekben további 12-15 db elektromos midibusz beszerzését is tervezi a cég (Közlekedés Fővárosi Tervező Iroda Kft. 2017).

\section{Elektromos töltőhálózat}

Az elektromos autó-, és autóbuszközlekedés elöfeltétele a töltőhálózat bővítése. Az önkormányzat jelenleg elsősorban az ingyenes parkolás lehetőségével tudja támogatni a zéró emissziós közlekedést, mely intézkedés Miskolcon már bevezetésre került. Az elektromos midibuszokhoz szükséges töltő infrastruktúra kiépítése is tervezés alatt áll, mely a lakosság igényeit is szolgálná, így bevételi forrást is jelentene (Közlekedés Fővárosi Tervező Iroda Kft. 2017).

\section{Mobiltelefonos applikáció}

Az egyik leghatékonyabb módja az utasok tájékoztatásának egy olyan integrált applikáció létrehozása, amelyen mind a közösségi közlekedési információk (menetrendek, valós idejü menetidők, menetjegyek), mind pedig a közös adatplatform közúti forgalmi adatai elérhetők 
lennének. A MobilOn applikáció jelenleg mindössze az autóbusz-, valamint villamosjáratok információiról ad tájékoztatást, azonban hatalmas potenciált rejt magában. További funkcióként össze lehetne kapcsolni a Mobiljegy applikációval, így jelentős adatmennyiség állna rendelkezésre az utazóközönség szokásairól, illetve a forgalomirányítási rendszer adatai segítségével az autósoknak is lehetőséget nyújtana a valós idejű forgalmi menetidők kiszámítására, esetlegesen alternatív útvonalat felajánlva, amely tovább csökkentené a torlódások kialakulásának esélyét. A kerékpárosok útvonalainak megtervezése, a kerékpártárolók megjelenítése is integrálható az alkalmazásba, amellyel szintén a városi közlekedés emissziójának csökkentése érhető el (Közlekedés Fővárosi Tervező Iroda Kft. 2017).

\section{Igényvezérelt menetrend}

A közös adatplatform adatainak elemzése által igényvezérelt menetrend lenne kialakítható, amely igazodik az utasok mobilitási szükségleteihez, így felesleges kapacitások nem keletkeznének. Az alacsony forgalmú időszakokban a kisebb méretü járművek indítása is célszerü lehet. Annak érdekében, hogy az idősek és mozgásukban korlátozott személyek közlekedése egyszerübbé váljon, eseti szállításakor szükséges háztól-házig járatok indítása is megvalósulhatna. Egy iskolabusz program keretén belül elektromos céljáratok szállíthatnák a tanulókat biztonságos közlekedési lehetőséget nyújtva (Közlekedés Fővárosi Tervező Iroda Kft. 2017).

\section{Fejlett úthálózat}

Miskolc esetében az egyik fő probléma az útburkolatok romló minősége, így elengedhetetlen az úthálózat jól átgondolt tervek szerinti fejlesztése. Várhatóan az útburkolatok minőségi javítása pozitív hatást gyakorol majd a városi forgalom dinamikájára is. Mindezek mellett érdemes megvizsgálni az autóbuszsávok további kiépítésének lehetőségét, hiszen ezzel nagy mértékben nőhet a közösségi közlekedési szolgáltatás hatékonysága a menetidők lerövidülése és a jobb tervezhetőségnek köszönhetően, mivel így a közösségi közlekedést kiszolgáló jármüvek kevésbé lennének kitéve a forgalmi viszonyoknak (Stringer 2017).

A javaslatok szerinti modell így a jelenlegi alacsony költséghatékonysággal szemben magasabb bevételek generálására lenne képes, mivel a magas minőségü szolgáltatást szélesebb körben vennék igénybe, illetve a kiegészítő szolgáltatások (pl. elektromos töltőpontok) további bevételi forrást jelentenének, így a bevételeket nem csupán a buszos közszolgáltatás révén kellene megteremteni, ezáltal az önkormányzati forrásokat fejlesztésekre lehetne fordítani a veszteségfinanszírozás helyett.

\section{Összegzés}

A tanulmány első részében ismertetett eltéréselemzés során megállapítottuk, hogy milyen jelentős hatása van a menetrendi korrekciónak. A manuális számítás nehézségei és nagy mennyisége miatt azonban javaslatunk alapján Miskolcon egy olyan okos informatikai rendszer kialakítására van szükség, mely képes kezelni a nagyméretü adatbázist, így nem lenne szükség olyan hosszadalmas számításra, melyet jelenleg is alkalmaznak. A miskolci közlekedési mintázatok algoritmikus vizsgálatával csökkenthető lenne a menetrendtől való eltérés, illetve a közlekedési fennakadások száma, valamint a balesetek megelőzésére is lehetőséget adna, hiszen feltárná a kritikus közlekedési pontokat és helyzeteket. Továbbá a fejlesztés a környezeti terhelést is enyhíthetné, illetve a felhasználói igényekhez való igazodást, a kényelmet és biztonságot is szolgálná (Hashem et.al 2016). Az általunk felvázolt jövőkép részletek segíthetnek integrálni Miskolc közlekedésfejlesztési koncepciójának elemeit is, melyek kölcsönös elönyökkel szolgálnának mindhárom azonosított érintett fél számára. A miskolci okos mobilitási ökoszisztéma ezáltal a modern kihívásokra válaszolni képes, hatékony és adaptív rendszerként müködhetne. A modell így a jelenlegi alacsony költséghatékonysággal szemben magasabb bevételek generálására lenne képes, mivel a magas minőségü szolgáltatást szélesebb körben vennék igénybe, illetve a kiegészítő szolgáltatások (pl. elektromos töltőpontok) további bevételi forrást jelentenének, így a bevételeket 
nem csupán a buszos közszolgáltatás révén kellene megteremteni, ezáltal az önkormányzati forrásokat fejlesztésekre lehetne fordítani a veszteségfinanszírozás helyett.

\section{Köszönetnyilvánítás}

A kutatást az EFOP-3.6.2-16-2017-00007 azonositó számú, Az intelligens, fenntartható és inkluziv társadalom fejlesztésének aspektusai: társadalmi, technológiai, innovációs hálózatok a foglalkoztatásban és a digitális gazdaságban címü projekt támogatta. A projekt az Európai Unió támogatásával, az Európai Szociális Alap és Magyarország költségvetése társfinanszírozásában valósul meg.

\section{Irodalomjegyzék}

ERHART, SZ. (2007): A budapesti közlekedési dugók okai és következményei, Közgazdasági Szemle, LIV. évf., 2007. május, p. 45123.

FÖLDES, D. (2019): Innovatív közlekedési rendszerek és szolgáltatások fejlesztése. (Doktori $(\mathrm{PhD})$ értekezés) Budapesti Müszaki és Gazdaságtudományi Egyetem, Közlekedésmérnöki és Jármümérnöki Kar, Közlekedésüzemi és Közlekedésgazdasági Tanszék, Budapest pp.20-34

GIFFINGER, R. ET AL. (2007): Smart Cities: Ranking of European MediumSized Cities, Centre of Regional Science, Vienna University of Technology

HALL, R. E. (2000): The Vision of a Smart City In Proceedings of the 2nd International Life ExtensionTechnology Workshop, Paris, France

HASHEM, I. A. T. EL.AL. (2016): The role of big data in smart city, International Journal of Information Management, 36(5), 748-758, https://doi.org/10.1016/j.ijinfomgt.2016.05.002

KOMNINOS, N. (2011): Intelligent Cities: Variable Geometries of Spatial Intelligence Intelligent Buildings International 3 (3): 172-188.

KÖZLEKEDÉS FÖVÁROSI TERVEZÖ IRODA KFT. (2016): Miskolc fenntartható mobilitási tervének (SUMP) felülvizsgálata http://miskolcvaros2020.hu/sites/default/files/dokumentumok/miskolc_sump_biralat i dok 1-fejezet.pdf (letöltés: 2020.10.07.)

KÖZLEKEDÉS FÖVÁROSI TERVEZÖ IRODA KFT. (2017): Miskolc megyei jogú város közlekedésfejlesztési koncepció és program - Koncepciós elemek kidolgozása

MVK MISKOLC VÁROSI KÖZLEKEDÉSI ZRT. (2013): Miskolc Város Fenntartható Közlekedési Terve - SUMP of Miskolc http://kerekparosmiskolc.net/wpcontent/uploads/2013/12/Miskolc_SUMP_MVK_131030_v\%C3\%A9gleges.pdf (letöltés: 2020.10.01)

NAGY, Z. ET AL (2015): Smart Local Community kezdeményezések lehetőségei vidéki térségekben - Borsod-Abaúj-Zemplén megye három járásának példáján. ÉszakMagyarországi stratégiai füzetek, 12 (2). pp. 59-70. ISSN 1786-1594 24.

PRICEWATERHOUSECOOPERS (PWC) MAGYARORSZÁG KFT (2016): Merre tovább a hazai autóbuszos közösségi közlekedésben? https://www.pwc.com/hu/hu/kiadvanyok/assets/pdf/helyi_autobuszkozelekedes.pdf (letöltés: 2020.10.09.)

SAJTOS, L. - MITEV, A. (2007): SPSS kutatási és adatelemzési kézikönyv, Alinea Kiadó, Budapest, 93 p., ISBN 978-963-9659-08-7.

SALLAI, GY. (2018): Az okos város koncepciója, In. Sallai Gyula (szerk.): Az Okos Város (Smart City) Dialóg Campus Kiadó, Budapest 
SÁNDOR, Z.- CSISZÁR, C. (2013): Késési események elemzése helyi autóbusz közlekedésben., IFFK konferencia 2013, Budapest ISBN 978-963-88875-3-5 53

STRINGER, S. M. (2017): The Other Transit Crisis: How to Improve the NYC Bus System, Office of the New York City Comptroller, NYC https://comptroller.nyc.gov/wpcontent/uploads/documents/The-Other-Transit-Challenge.pdf (letöltés: 2020.10.15.)

SZENDI, D. (2019): Measuring the smart cities' performance in the capital cities of the EU Proceedings of the International Conference - Special mechanism and policy for the development of Ho Chi Minh City from the legal perspective pp. 87-120., Ho Chi Minh City, Vietnam

SZLÁVIK, J. (2013): Fenntartható gazdálkodás. CompLex Kiadó, Budapest, 273 p. 59 